\title{
Symbolism, Aesthetics, and Narrative in Rock Art
}

\author{
Jamie Hampson \\ Department of History, University of Exeter, Cornwall, UK, J.G.Hampson@exeter.ac.uk
}

\begin{abstract}
A San (Bushman) rock art site in the Free State Province of South Africa is considered by local inhabitants to depict specific historical events of the nineteenth century. This chapter describes the paintings and dispels these 'romantic' myths. Using ethnographic evidence, albeit with a healthy dose of Clegg-like caution, it is argued that the site is not a mere 'narrative' of actual events but rather a symbolic manifestation of the cosmological belief systems of the San.
\end{abstract}

Key words: San (Bushman), Boers, rock art, narrative, memoriolization, symbolic meaning, frontier conflict

\section{Introduction}

Regardless of where we work, John Clegg's words help us to think carefully about the relationships between aesthetics, symbolism, rock art, and its (discernible) meanings - or, more often, apparent lack thereof. When I first met John, at a British Rock Art Group Conference in Newcastle in 2004, I was based at the University of Cambridge and working in under-studied areas of southern Africa and west Texas. Grappling with the slippery notions of regional rock art 'styles', I was interested in the significance we - and arguably the original artists - attached to both differences and similarities (Hampson et al. 2002; Hampson 2004, 2011, 2015a). John talked to me about the marvellous Aboriginal engravings close to Sydney (Clegg 1978, 1998; McDonald 2000, 2008) and the problems he encountered when attempting to recognize 'scenes' and 'narrative' (Clegg 1987, 2001, 2003). Even identifying specific motifs, he said, could be fraught with danger:

The general assumption is that a picture is of that target object which it resembles most closely. This assumption satisfactorily and transparently begs many questions. It works with minor modifications also as a definition of depiction: A picture is a depiction insofar as it resembles an object or concept. (Clegg 1978: 104.)

Although the history of rock art research in each continent differs greatly (e.g. Whitley and Clottes 2005; Hampson 2015a), at a large scale there are similar, albeit nuanced, themes; the last sentence of the Clegg quotation above certainly applies everywhere. Most importantly, confidence of what actually happened in the past, wherever we work, is clearly a matter of degree. Only the staunchest nihilist will claim that we know nothing about the past, or deny that some explanations are more compelling than others. Otherwise, why bother going into the field and collecting data?
Few rock art researchers working in southern Africa today question the notion that San rock art was produced within some kind of ritualistic framework even when there is no 'direct' or regionally specific ethnographic evidence available. On a broad (but certainly not absolute) level, we know that San paintings and engravings in numerous southern African regions indicate a belief in a tiered cosmos and the interpenetration of cosmological tiers by ritual specialists (Lewis-Williams 1981; Lewis-Williams and Dowson 1989; Hampson et al. 2002; Lewis-Williams and Pearce 2004; Hampson 2013). Again, as per Clegg's 1978 quotation, rock paintings and engravings resembled - and indeed manifested - not only objects but also concepts. Motifs were not simple depictions of everyday, mundane items.

Relating rock art to concepts and belief systems such as ritualism, animism, or shamanism does not remove it from the historical arena. Nor does this emphasis on ritualism discount the importance of aesthetics - however we define the term. Indeed, David Whitley (2005: 10), in his review of Heyd and Clegg's (2005) Aesthetics and Rock Art, points out that researchers have for along timeincorporated an appreciation of aesthetics into rock art research (e.g. Morphy 1994; Skotnes 1994; Morales 2005). Similarly, despite Solomon's (2011: 54) claims to the contrary, I do not claim that an aesthetic approach to regionalism is 'useless'. As Solomon (2011: 54) herself points out, I highlighted the 'confusion about where style [in an aesthetic sense] resides', and was explicit about the fact that I deliberately excluded aesthetics (however defined) as a criteria in my and my colleagues' initial study in Mpumalanga (Hampson et al. 2002). I did this precisely because we can learn more about regionalism from the presence or absence of certain motifs. Moreover, the heuristic potential of ethnography-driven frameworks has allowed recent studies (e.g. Blundell 2004; Challis 2012, 2014; Mazel $2009,2013)$ to focus on social - and sometimes even 


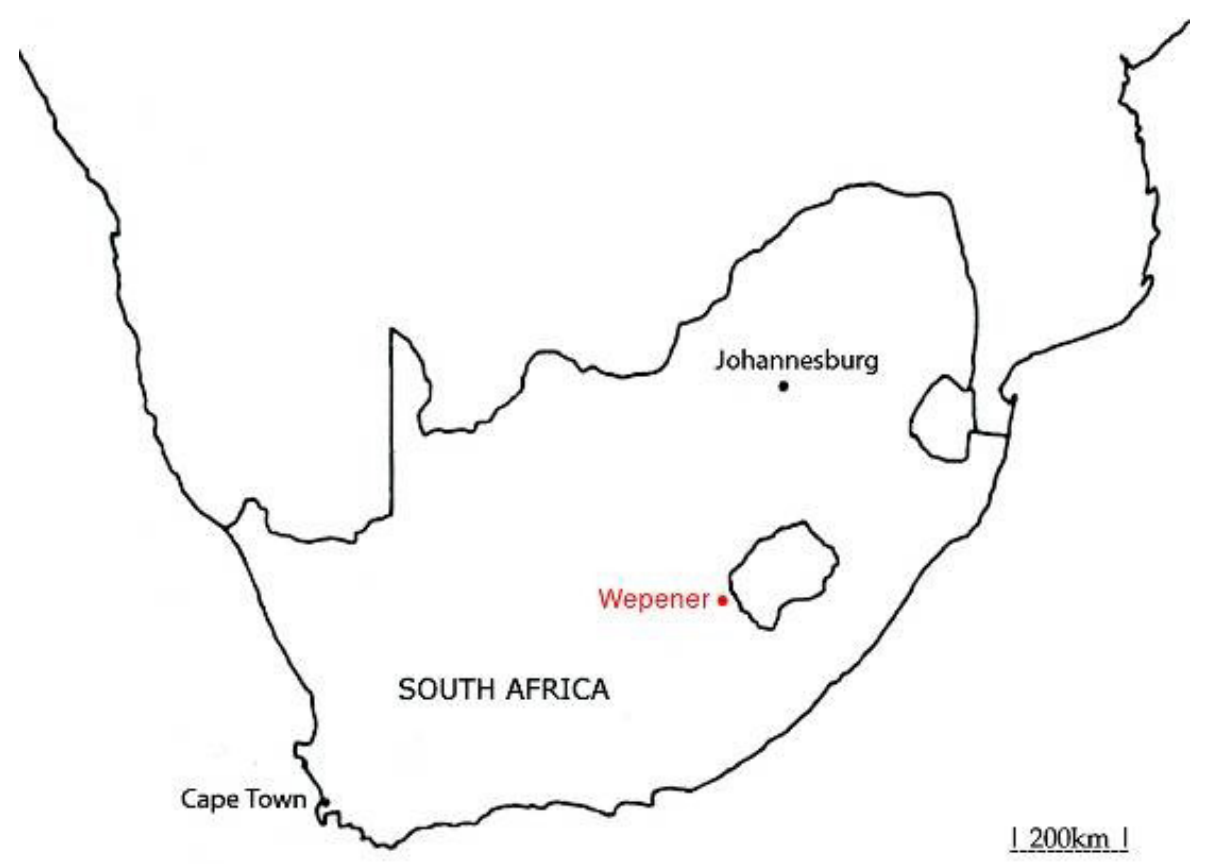

Figure 75. Map showing the town of Wepener, close to the South African border with the land-locked country of Lesotho. six Bushmen were arrested and subsequently hanged in Bloemfontein, the provincial capital about 80 kilometres distant (Collins 1907: 15). Wepener locals believed that one member of the original group escaped and fled towards the Caledon River, a few kilometres from the burned house (van Hansen 1859: 134; Collins 1907: 15; Hampson 2014; Christie personal communication 2000). It is this alleged escapee whom the Wepener locals believe may have depicted these historical events in the BOS 1 rock shelter. Before addressing the authorship of the rock art images, I outline the nature of frontier society in

individual - histories, and to incorporate rock art into not only the study of the past but also into the immediate significance of the present (e.g. Smith et al. 2012; Hampson 2015a, 2015b). An art-historical approach, or appreciation of the aesthetics of rock art, can usefully augment ethnography-driven frameworks: the two approaches are not mutually exclusive.

When we talk about history, however, a key question remains: Even if we can confidently attribute specific paintings to individual artists, pace Clegg's warnings, does San rock art ever depict or commemorate particular historical events in a strictly narrative sense? By investigating the remarkable paintings at the BOS 1 rock shelter in the Free State Province of South Africa (Figure 75), I offer suggestions as to how researchers might begin to answer this deceptively simple but often overlooked question.

Local histories in the Free State: conflict in a frontier society

In 1850, near the town of Wepener in the Free State Province, a Bushman or San man named Maglatsi asked a European bywoner farm tenant - a man named van Hansen - for tobacco. Van Hansen kicked Maglatsi, and refused. Later that day, Maglatsi and at least twelve other Bushmen attacked and set alight van Hansen's house, and killed him, his wife, their three children and two Khoe-speaking ('herder') servants (van Hansen 1859: 134; Collins 1907: 15; Midgely 1949: 270-271; Hampson 2014: 104). A Boer commando, aided by a Cape corps and local San trackers, located van Hansen's attackers and during a skirmish killed six of them. The remaining the (Orange) Free State during the nineteenth century. Violent and non-violent conflicts were not uncommon, as in most regions of creolization (Lightfoot 1995; Lightfoot and Martinez 1995; Challis 2008, 2012).

Besides the San (Maglatsi and his colleagues) and the Boers (the van Hansens), there were British and French missionaries, deserters from British and German armies, Khoe herders and other Khoe-speaking native groups (including Koranas), Afrikaans-speaking Griquas and Bastaards, Sotho-speaking clans of various allegiances (including Batlokwa or Mantatees), and more. Many of these groups were often involved in disputes over land and property rights (Stow 1905; Collins 1907; Etherington 2001; Ouzman 2005; Challis 2012).

In the late 1700 s, before the competition for territory intensified, the San had occasionally welcomed the Boer hunting parties that came north from the Cape, usually because of the feasting that followed the slaughter of hippo and other large game by the farmers' muzzle-loaders (Van der Merwe 1936; Dracopoli 1969; Etherington 2001; Christie personal communication 2000). By the nineteenth century, however, these intergroup hostilities took the form of regular warfare waged against the San by the Boers, British, Sotho and other agricultural settlers. Despite treaties between the groups - treaties that were often made, broken, re-made, and broken again - the relationships among the farmer-settlers and the hunter-gatherer (and increasingly creolized) San were marked by profound distrust and prejudice. According to George Stow (Stow and Bleek 1930: 215): 
The pastoral tribes of natives and colonial flock owners could not appreciate the feelings of attachment which those who lived by the chase alone had to their hunting grounds. ... Their ... utter contempt for all pastoral or agricultural pursuits, made them to be looked upon by all the larger and more robust of the African races as a species of wild animal which it was praiseworthy to exterminate.

By 1850 , Bushmen were frequently indentured by settlers and sent to work for farmers in and around Bloemfontein (Midgely 1949: 270; Legassick 1989; Etherington 2001). After the killing of van Hansen and his family, at least one hundred San in the area were arrested and put into Boer service, although many of these men and their families escaped and fled to the hills (Midgely 1949: 270; Christie personal communication 2000). For the most part, the raiding and stealing of Boer cattle stopped, except for a few instances when Bushmen allied with Basotho chiefs (Midgely 1949: 271; Etherington 2001). In fact, it was rumoured that Maglatsi and his allies were adherents of the minor Basotho chief Poshili (Collins 1907: 15; Christie personal communication 2000). On the other hand, there is also evidence to suggest that Boers employed Basotho chiefs (such as Malapo) to arrest and even to kill the San who escaped after the patrols and arrests of the early 1850s (Montgomery 1914: 108). In a creolized frontier society, allegiances rapidly altered.

In addition to ethnographic and historical evidence, archaeological artefacts confirm that there was multidirectional contact between farmers, pastoralists and hunter-gatherers. European bullets, metal, and cloth have been found in rock shelters in the Caledon District alongside Bushman stone tools and grindstones (Wright 1971; Sampson 1974; Brooker 1980).

\section{The BOS 1 painting}

With those complexities of the nineteenth century frontier society in mind, I now consider the San painting at BOS 1 in a shallow rock shelter close to the Caledon River. The rock art - in faded red, black, and white pigments - is not well known in the area (cf. Brooker 1980; Hampson 2014). Local farmers who are aware of its existence have for some years suggested that it depicts the skirmish between the fugitive San and retaliating Boers after the murder of van Hansen and his family. They believe the individual that survived and fled to the river may have painted it (Christie personal communication 2000). Although many researchers - including John Clegg - have successfully argued that the 'common sense' or 'gaze-and-guess' approach to rock art interpretation will almost certainly lead to false conclusions, the suggestions of the local Wepener farmers raise interesting issues regarding San rock art and historical events. It is possible that a fugitive San artist produced rock art - including the images in BOS 1 - at some point after the events of 1850 . But how likely is it that these images depict a specific incident? In order to answer this question, and before considering the applicability within the San worldview of the word 'depict', I describe the remarkable painting and adumbrate some of the pertinent motifs.

\section{Painted history?}

Two groups - or what some researchers have dubbed 'processions' (Smuts 1999; Hampson et al. 2002: 18) - of human figures are depicted in the main panel at BOS 1 (Figures 76 and 77). One group, painted in black, faces the left of the panel, and the other, predominantly red, faces the opposite direction. Bearing in mind that when attempting to identify 'scenes', some researchers (e.g. May and Domingo Sanz 2010) are more confident than others (e.g. Clegg 2003; Dobrez 2011), I explicitly divide the figures into six somewhat arbitrary groupings in order to show the detail in the re-drawings and photographs.

There are twelve black figures to the left of the panel, each of whom holds a club-like piece of equipment in their raised right hands. The legs of these figures are unusual: the calf muscle is not as clearly defined as it is in other San paintings. John Clegg would have called the three dog-like animals !dogs, by his convention that the exclamation mark indicates a resemblance - in these cases to a dog, real or conceptual. These three !dogs separate into two sub-groups, each of six: on the left, subgroup 1 has six human figures with penises; on the right, subgroup 2 has six human figures without discernible penises. Each figure in subgroup 2 is touching their waist with their left hands; across their waists are three parallel lines. Three figures in subgroup 1 also have their left hands at their waists, but there are no parallel lines. The human figure at the rear of this subgroup, closest to the canines, has his left arm outstretched, towards them. The only figure in the entire panel with their head turned backwards is the leading figure in subgroup 2 to the right of the !dogs.

26 of the 29 human figures in subgroups 3-6, on the right side of the panel - most painted predominantly in red - have an emanation from the shoulder, protruding behind them towards the left of the panel. In subgroup 3 are seven figures, all in red, and each with a white band across the waist and another across the shoulder. Four of these figures have similar white bands across the knees; two also have white bands around the ankles.

Farther to the right is another procession of six figures, subgroup 4. The three at the far end of the panel partially obscured by a calcite wash. At least five of these figures have white bands across the waist and shoulder; none has bands across the knees or ankles; 
all have emanations, some longer than others, from the shoulders.

Below the red figures of subgroup 3 is a line of nine figures, subgroup 5 (Figure 78). The eight red and one black image all face to the right. The eight red have an emanation from the shoulders; the black figure does not. One smaller red figure, second from the left and the only one with white bands across waist and shoulders, seems to carry a stick-like object in one hand. Six of the figures, including the one in black, are partially hidden by a disproportionately large white bag-like object from which 31 black 'tassels' emanate; two of these tassels overlap.

Subgroup 6, the last subgroup on the far right side, has at least seven figures. One is red; the others are black and red - usually with a black torso outlined in red. Four have emanations from the shoulders; the first four in line are partially covered by another and smaller white bag-like object with approximately 24 red tassels. One of the figures has a white torso. To the right of the seven figures, another white bag-like object covers remnants of red pigment, most probably additional figures. Although the calcite wash obliterates most details of this third bag-like object, three black tassels can be seen to emanate from the right hand side.

In sum, these four sub-groups 3-6, on the right of the panel, comprise at least 29 figures; only one is depicted entirely in black. Nearly all have emanations from the shoulders; many possess white bands across the waist, shoulders and ankles. In contrast, the sub-groups 1 and 2, facing left, contain 12 black figures. All carry clublike objects, and six have parallel lines across the waist.

Who are these faded depictions of? On the right, the van Hansen family and the Boer authorities, eager for revenge after the attack on the homestead? Are these the red figures who appear to be clothed and carry weapons? And to the left, the naked, fugitive Bushmen, fleeing for their lives? There is an attractive romance to this vivid story. Narratives, especially those that involve arson and bloodshed, excite. Good answers to these questions depend on aspects of the polysemic complexity that underlies southern African San rock art.

\section{San rock art and historical narrative}

We can no longer be content with a 'gaze-and-guess' approach to rock art when rich ethnographic and historical resources are available: John certainly was not! Many early travellers and researchers in South Africa (e.g. Kolben 1731; Barrow 1801; Alexander 1837; Tindall 1856; Balfour 1909), as well as those later in the twentieth century, were ignorant of these ethnographic resources, or unwilling to use them; so they justified gaze-and-guess by asserting that the meaning of the art was self-evident: depictions by 'primitive people' that reflected 'daily life'. Balfour (1909: 8) in particular spoke of the 'representations of scenes and events in Bushman life-history', implying that rock art could be 'read' as easily as the reports of early colonial travellers. Disastrously, the act of 'reading' the narrative putatively inherent in the images - and the subsequent induction of meaning from that reading - was considered straightforward. Until the development of heuristic models revolutionized study in the 1970s and beyond (e.g. Lewis-Williams 2006), the complexity and ritualistic nature of San art was overlooked. Alistair Paterson (2012: 70) has also recently warned us of the pitfalls of a linguistic 'reading' of 'contact' era indigenous rock art, 'an area of study where so much weight is given to those historical sources, both written and pictorial, that reflect a European's understanding of a multicultural event'.

San and creolized-San paintings featuring European and Nguni-speaking settlers are widespread throughout southern Africa (e.g. Vinnicombe 1976: her Figures 12-15; Johnson 1979: his Figures 97, 98; Campbell 1986; Lewis-Williams and Dowson 1989; Dowson 1994; Loubser and Laurens 1994; Thorp 2000; Ouzman 2003; Challis 2008). Several of these contact-era paintings unequivocally show European, Nguni-speakers, or creolized settlers - or their accompanying material culture: clearly painted wagons, horses and rifles, cattle, and other domesticated animals, including dogs. The simple depiction of these items, however, does not unambiguously denote European arrival. Dogs, for example, were domesticated before the colonial era, and non-European groups also had wagons (Brooker 1980; Lewis-Williams 1983: his Figures 83-87; Ouzman 2003; Loubser and Laurens 2004; Challis 2008).

Many colonial-era contact paintings also incorporate features that point to a ritualistic context (Vinnicombe 1976; Campbell 1986; Lewis-Williams and Dowson 1989; Dowson 1994; Ouzman 2003; Challis 2008, 2012). These features highlight the fact that rock art - whether produced during or prior to the arrival of Khoe-speaking herders, Bantu-speakers or European farmer-settlers - was not made 'merely' to record or commemorate events. Western-style narrative and commemoration is not universal to human image-making or to image-meaning, so looking at paintings made by hunter-gatherers and other non-Western groups through Western eyes and with that Western habit of painting commemorations of famous events yields flawed interpretations. Even specific historical events in San rock art are, in fact, implicated in ritualistic beliefs and rituals.

The power relations between Bushmen, farmersettlers, and other groups were unbalanced. Because the numbers of nineteenth century San communities were so reduced and resources so greatly diminished in 
many regions in southern Africa, hunter-gatherers and herders in order to survive were obliged to forge new relationships with their agro-pastoralist neighbours both European and Nguni-speakers. Importantly, San, herder, and creolized groups forged these relationships within their extant socio-political frameworks and indigenous world-views (Dowson 1994; Thorp 2000; Ouzman 2003; Blundell 2004; Challis 2008, 2012). On the other side of the cultural divide, many farmers believed that the San's rain-making abilities could determine the outcome of their harvests; so they both feared the Bushmen and acknowledged their dependence (Jolly 1996, 1998; Thorp 2000; Mitchell 2002). Where we do find unequivocal depictions of settlers in San rock art, these images do not necessarily depict conflict; rather, they are concerned with socio-cultural and political negotiation (Dowson 1994; Ouzman 2003; Blundell 2004; Challis 2008, 2012).

As Thomas Dowson (1994: 333) has argued: 'Bushman shaman-artists were using two of their traditional techniques (entering the spirit world and making rock art) to engage the new threat' - the threat posed by the European and Nguni-speaking settlers. Once the settlers made an impact, characters in the spirit world included not only Bushman spirits, but also the new arrivals, as settlers became involved in the social production of rock art. Depictions of Europeans and other agriculturalists, therefore, represent the San negotiation of power with those settlers in the spirit world; there is no evidence to suggest that actual (historical) events - whether antagonistic or not - are depicted. Moreover, the production of rock art, both before and after the arrival of European settlers, was an engaging process; paintings were not simply illustrative, commemorative, representative, or reflective depictions - they were powerful things in themselves, and reservoirs of potency (Lewis-Williams and Dowson 1989; Lewis-Williams 1995; Lewis-Williams 2006; Hampson 2016).

\section{Sotho, San, bags, and ritualistic contexts}

There is another aspect to the rock art panel at site BOS 1 usefully to be explored. As with most rock art sites in southern Africa, we do not know exactly who painted the images. Neither do we know how old the paintings are (cf. Bonneau et al. 2011, 2012); they may or may not pre-date the arrival of agro-pastoralist groups. This chronological uncertainty is not an issue for the argument developed here; more important is the unlikeliness that the ritualistic images illustrate a literal or narrative event. Because San (and creolized San) paintings are contextual and ritualistic, they are always more than mere narrative - they were not produced simply to 'tell a story'. Despite the historical accounts of San being 'shot out' by a Boer commando, and of Cape corps close to the rock shelter, then, it is improbable that a) the red figures in the rock art are Boer (or European) soldiers; $b$ ) that the black figures are fugitive Bushmen; or, especially, c) that, together, the paintings depict the events of 1850 .

The figures painted in black (Figure 76 subgroups 1 and 2) may depict Sotho men. If this is right, then the painting does not show the 1850 confrontation in a narrative sense, since the Sotho were not involved. Why might the black figures depict Sotho men? The three parallel lines across their waists resemble Sotho shields, depictions of which are also found at many rock art sites near by (Vinnicombe 1976; Brooker 1980; Ouzman 2003; Loubser and Laurens 2004; Christie personal communication 2000). Also on neighbouring farms is an abundance of unequivocal images of cattle, sheep, and Sotho warriors; contact art is not uncommon in the Caledon River valley (Brooker 1980; Ouzman 2003; Christie personal communication 2000). As Clegg always reminded us, resemblance is not enough to develop convincing conclusions (e.g. Clegg 1998, 2001, 2003), but Sotho warriors also carried club-like knobkerries (Campbell 1986: 261) and owned hunting dogs (Lee 1999) - not unlike those on the left of the painting at BOS 1 . The absence of the calf muscle also suggests (but by no means proves) that the artists were not depicting Bushmen, and nothing about the figures suggests that the black figures represent Boer settlers. Exactly why the San may have depicted Sotho figures is a more difficult matter which I do not attempt to unravel here, other than by reiterating the importance of the concept of San negotiation with the newly arrived settlers, in both the real and the spirit world, through the ritualistic act of painting.

The red figures (Figure 76, subgroups 3-6) facing in the opposite direction to the black ones might depict soldiers, but they are most probably depictions of Bushmen; they are consonant with what we know of San rock art and cosmology, and also consonant with the 'style' of Bushman human figures. To see the emanations from the shoulders as images of guns, and the white bands across waist and shoulders as belts and bandoliers is not enough: evidence is required. As outlined earlier, San paintings before the 'contact-era' did not have a habit of literal realism (in the European manner of painting), and there is no evidence to suggest that the arrival of Europeans and other settlers caused those enduring rules of San art to be broken. The several ritualistic components in the paintings suggest that the procession of both red/black and also red figures to the right of the panel are connected in some way to shamanistic activity, and to the dance used to achieve altered states of consciousness and entry into the spirit world (Lewis-Williams 1981; Lewis-Williams and Dowson 1989; for discussion on processions see Smuts 1999; Hampson et al. 2002: 18). 


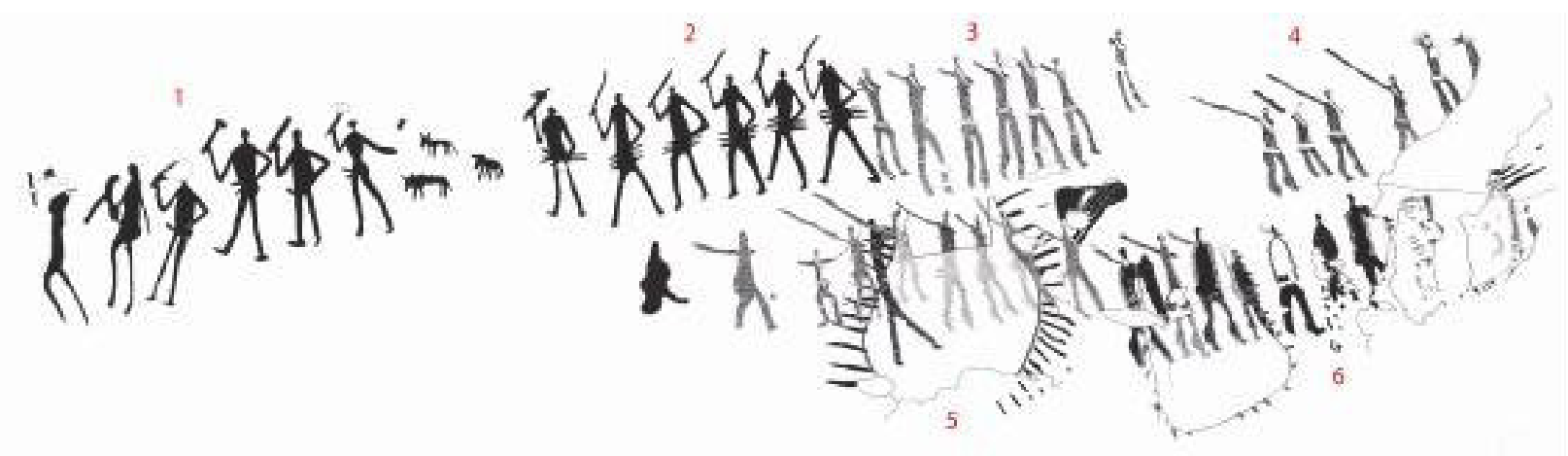

Figure 76. Redrawing of main panel at BOS 1 rock shelter, Free State Province, South Africa $(\sim 800 \mathrm{~mm} x \sim 200 \mathrm{~mm})$. Black represents black paint; stipple represents red.

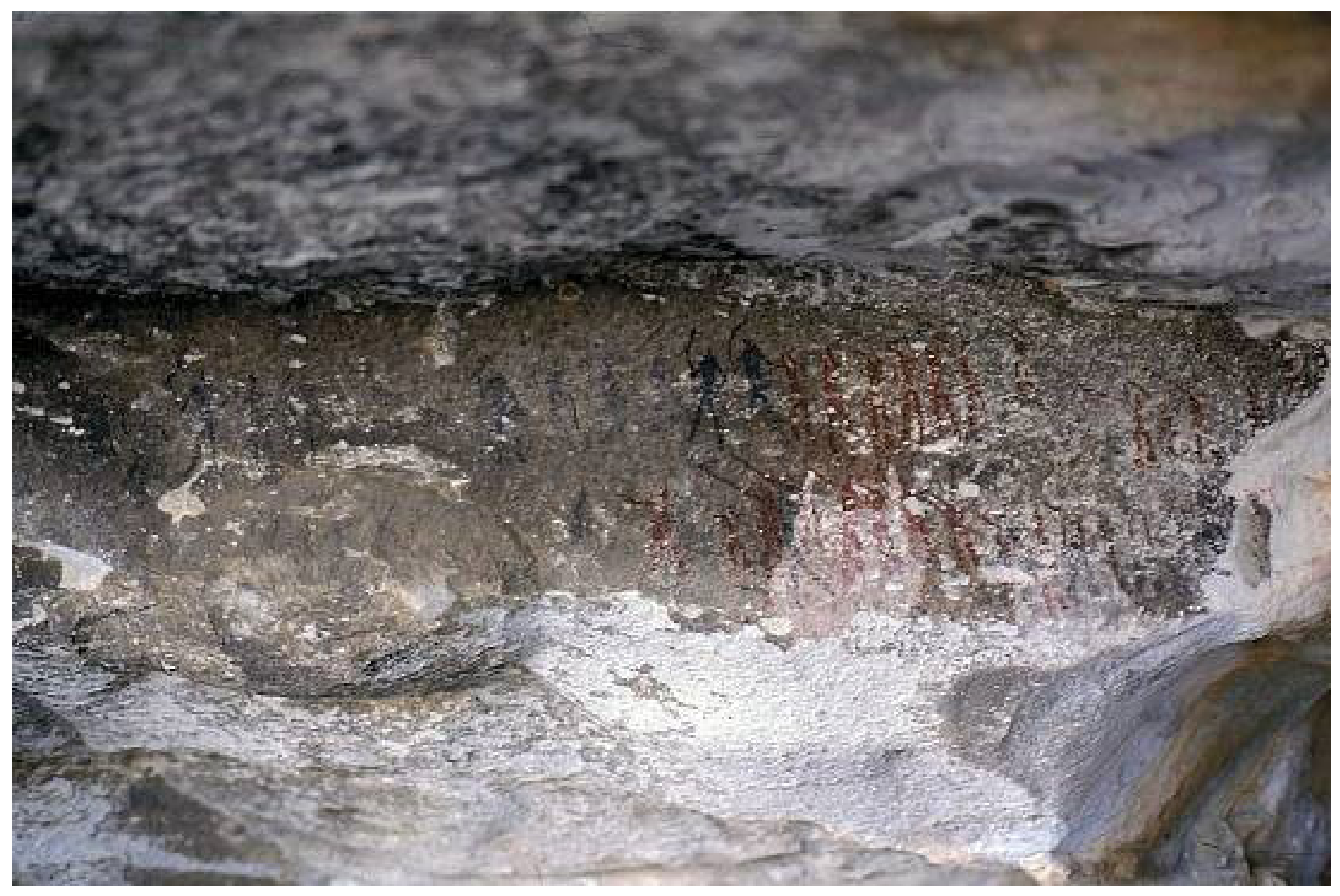

Figure 77. Photograph of main panel at BOS 1 rock shelter. Note the white bags at centre right, painted over the human figures. (Photo by J. Hampson.)

Although the white shoulder, waist, knee and ankle bands could depict military regalia, even if the red figures are depictions of European soldiers, the panel is not a simple, literal depiction, or representation, of a particular event described in the local history. We know that various San, Sotho, and creolized groups sometimes displayed this regalia, and that they possessed muskets and horses (Orpen 1874; Collins 1907; Jolly 1996; Challis 2008, 2012, 2014), but it is unlikely that the painted bands are physical objects or marks. Instead they probably refer to the sensation of constriction experienced by ritual specialists in trance, caused by boiling potency (Lewis-Williams and Dowson 1989). Bushmen in the Kalahari describe their stomach tightening 'into a balled fist' (Katz 1982: 46) and their sides being 'fastened by pieces of metal' (Biesele 1975: 155, 1980: 56). Similar symbolic depictions of this sensation are found in rock art panels throughout the sub-continent (e.g. Dowson 1989: his Figures 4-8; Hampson et al. 2002: 26). Moreover, as mentioned above, there are examples of unambiguous military accoutrements in many sites near by (Lewis-Williams 1983: his Figures 83-87; Ouzman 2003; Loubser and Laurens 2004). 


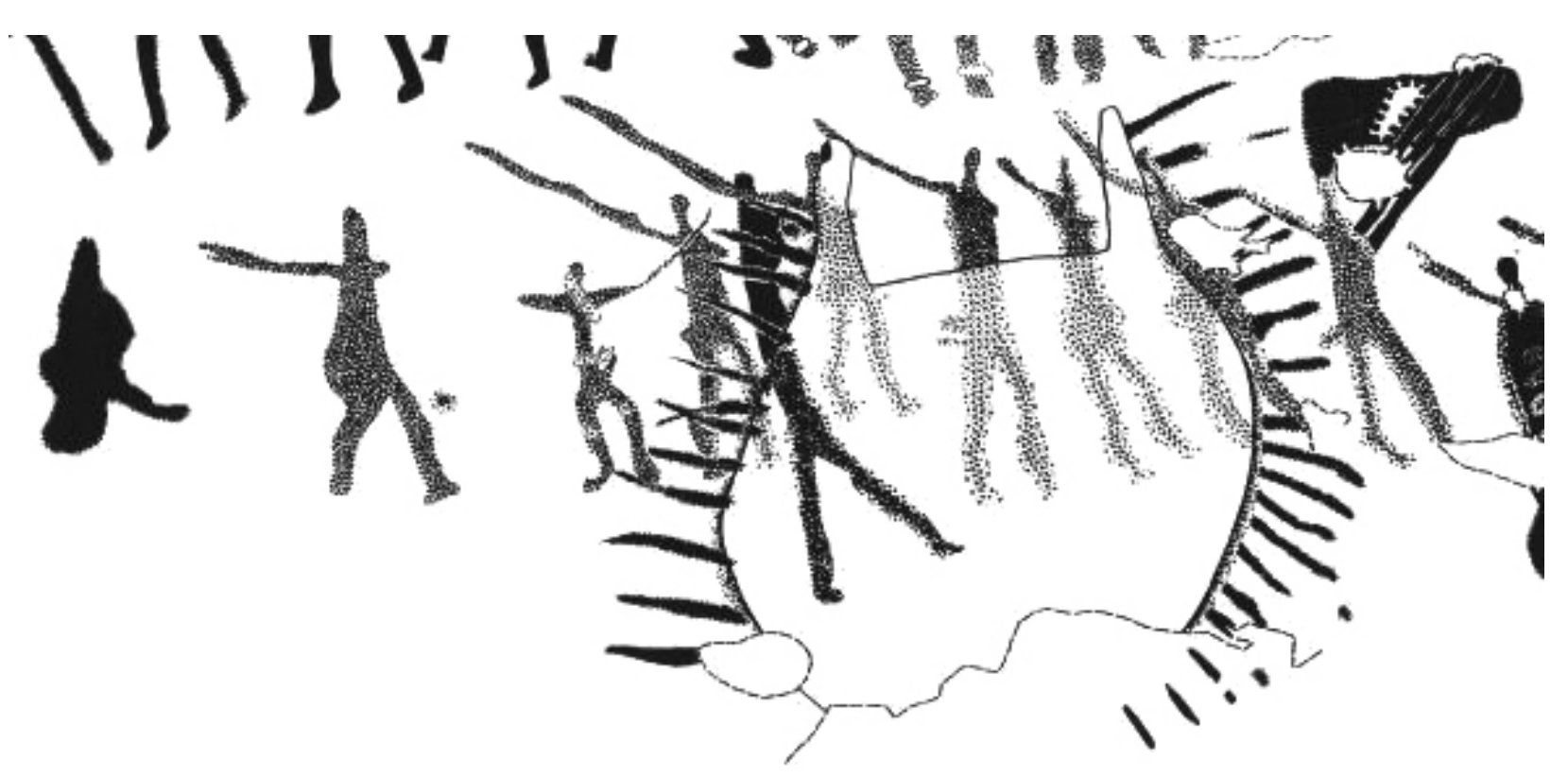

Figure 78. Subgroup 5 of main panel at BOS 1 rock shelter with white bag painted over human figures. The bag is $\sim 130 \mathrm{~mm}$ across.

The emanations from the shoulder also point to a ritualistic context. Although they have been described as poorly drawn rifles, ethnographic evidence again suggests an alternative: the lines represent the expulsion of sickness from the $\mathrm{n} / /$ ao spot at the nape of the neck (Lewis-Williams and Dowson 1989: 32). One of the tasks ritual specialists perform in an altered state of consciousness is to lay their hands on people to draw out 'sickness' and then return the sickness to its source - malevolent shamans in the spirit world - via the $n / / a o$ spot (Lewis-Williams and Dowson 1989: 32).

The meaning of the three superimposed bags (Figures 77 and 78) is clearer, and I suggest, significant. Bags were - and still are - of great importance to the San because they are imbued with potency. In the Kalahari Desert today bags are often made (by the Ju/'hoan San) from 'red meat' animals that possess $n / o m$, potency harnessed by ritual specialists (Lewis-Williams and Dowson 1989; Biesele 1993; Lewis-Williams and Pearce 2004). Interestingly, Bushmen do not necessarily distinguish between the word for an artefact and that for the substance of which it is made (Biesele 1993). In one San myth, A visit to the Lion's House, the lion hides in a bag. From this example, Lewis-Williams and Dowson (1989: 116) have argued that placing oneself in a bag is equivalent to placing oneself inside an animal, that is, to taking on its potency. In another myth, the trickster-deity and first shaman /Kaggen gets into a bag to hide and to change himself into a flying creature (Lewis-Williams and Pearce 2004: 120, 126). In at least one other panel in the Drakensberg, bags are shown transforming into eland (Vinnicombe 1976: Figure 107; Lewis-Williams and Pearce 2004: fig. 6.6). Bags, we can see, are obliquely associated with the dance and visits to the spirit realm.

The tassels on the bags are also significant: they are akin to shamans' hairs standing on end while in altered states of consciousness (Lewis-Williams and Dowson 1989; Hollmann 2002). The tassels may also be associated with what Patricia Vinnicombe (1976: 260, 344) dubbed 'thinking strings', metaphorical cords situated in the throat and associated with rain-making specialists.

Whomever the figures depict, the superimposed bags also and independently suggest that the context of the painted panel is ritualistic. Importantly, there is plenty of unpainted rock in the shelter: it is significant that the artist(s) chose to place the bags directly on top of the red figures, thereby incorporating them yet further into an indigenous and ritualistic ontology.

\section{A way forward?}

Interesting tangential questions arise at the Wepener site: Were the two distinct groups painted at the same time or hundreds of years apart? When were the superimposed bags painted? Why are some of the figures with emanations from the shoulder painted in black and red? Was colour significant to the artists? Why are some figures outlined (see also Hampson et al. 2002: 28)?

Detailed studies of San beliefs may provide the answer to these questions. Regardless, researchers cannot afford to avoid rich ethnographic resources, indispensable oral and written testimonies that, among other things, 
indicate clearly that San paintings do not depict actual historical events - at least not in the Western sense of commemorative narrative. Ethnographies have shown us not only that some beliefs are widespread, but also that many persist; as John Clegg made clear, researchers must always demonstrate - and not merely assume - change through space and over time. Although we must (obviously) proceed with caution, the hermeneutic and ritualistic models developed by rock art researchers in recent decades allow for further avenues of theoretically based research and methodology to be explored.

\section{Acknowledgements}

This paper stems from a talk I gave at the British Rock Art Group (BRAG) annual conference in 2004, where I first met John Clegg. I gave an extended version of this paper at the World Archaeology Conference (WAC) in 2008. I thank the organizers of the WAC session - Donna Gillette, Breen Murray, Mavis Greer, and Michele Hayward - for inviting me. Thanks also to James Christie for inviting Sam Challis and me to his wonderful farm near Wepener, and for his help with Free State history; to the editors of this volume for inviting me to contribute this chapter; and, especially, to Sam Challis for his Rapid Response company in the field in South Africa. Sam Challis and I traced the paintings at the Wepener site; Sally Coleman and Olivia Tuchten redrew them. Christopher Chippindale and Geoff Blundell kindly read drafts of this paper and offered useful suggestions. Finally, I thank Jo McDonald and everyone at the Centre for Rock Art Research and Management (CRAR+M) at the University of Western Australia (UWA), and also colleagues in the Department of Archaeology at the University of York, where I am finishing my Marie Curie Global Fellowship.

\section{References}

Alexander, J.E. 1837. Narrative of a voyage of observation among the colonies of western Africa in the flagship Thalia: and of a campaign in Kaffir-Land, on the staff of the commander-in-chief, in 1835. London: Colburn.

Barrow, J. 1801. An account of travels into the interior of southern Africa: a comparative ethnography of the Khoisan peoples. Cambridge: Cambridge University Press.

Balfour, H. 1909. Preface, in H. Tongue (ed.) Bushman paintings: 2-10. Oxford: Clarendon.

Biesele, M. 1975. Folklore and ritual of !Kung huntergatherers. Unpublished $\mathrm{PhD}$ thesis. Cambridge: Harvard University.

Biesele, M. 1980. Old K"xau, in J. Halifax (ed.) Shamanic voices: a survey of visionary narratives: 54-62. London: Penguin.

Biesele, M. 1993. Women like meat: the folklore and foraging ideology of the Kalahari Ju/hoan. Johannesburg: Witwatersrand University Press.
Blundell, G. 2004. Nqabayo's Nomansland: San rock art and the somatic past. Unpublished Ph.D. dissertation, University of Uppsala.

Bonneau, A., F. Brock, T. Higham, D. G. Pearce and A. M. Pollard. 2011. An improved pretreatment protocol for radiocarbon dating black pigments in San rock art. Radiocarbon 53(3): 419-428.

Bonneau, A., D.G. Pearce and A.M. Pollard. 2012. A mutli-technique characterization and provenance study of the pigments used in San rock art, South Africa. Journal of Archaeological Science 39: 287-294.

Brooker, M. 1980. Rescue excavations at the Welbedecht Dam site. Humanitas 6(1): 35-42.

Campbell, C. 1986. Images of war: a problem in San rock art research. World Archaeology 18(2): 255-268.

Clarkson C., Z. Jacobs, B. Marwick, R. Fullagar, L. Wallis, M. Smith, R.G. Roberts, E. Hayes, K. Lowe, C. X.Carah, S. A. Florin, J.McNeil, D. Cox, L.J.Arnold, Q. Hua, J. Huntley, H.E.A. Brand, T. Manne, A. Fairbairn, J. Shulmeister, L. Lyle, M. Salinas, M. Page, K. Connell, G. Park, K. Norman, T. Murphy and C. Pardoe (2017) Human occupation of northern Australia by 65,000 years ago. Nature 547: 306-310.

Challis, W.R. 2008. The impact of the horse on the AmaTola 'Bushmen': new identity in the MalotiDrakensberg mountains of southern Africa. Unpublished D.Phil. thesis. Oxford: University of Oxford.

Challis, W.R. 2012. Creolisation on the nineteenth century frontiers of southern Africa: a case study of the AmaTola 'Bushmen' in the Maloti-Drakensberg. Journal of South African Studies 38(2): 265-280.

Challis, W.R. 2014. Binding beliefs: the creolisation process in a 'Bushman' raider group in nineteenth century southern Africa, in J. Deacon and P. Skotnes (eds) The courage of //Kabbo and a century of specimens of Bushman folklore: 246-264. Cape Town: UCT Press.

Clegg, J. 1978. Mathesis pictures, mathesis words. Balmain: Clegg Calendars.

Clegg,J.1987. Human picturing behaviour and the study of prehistoric pictures. Rock Art Research 4(1): 29-35.

Clegg, J. 1998. Making sense of obscure pictures from our own history: exotic images from Callan park, Australia, in C. Chippindale and P.S.C. Taçon (eds) The archaeology of rock-art: 336-345. Cambridge: Cambridge University Press.

Clegg, J. 2001. Rock art studies: theory, in K. Helskog (ed.) Theoretical perspectives in rock art research: 40-67. Oslo: Novus verlug, The Institute for Comparative Research in Human Culture.

Clegg, J. 2003. How do we recognise rock art? TRACCE Footsteps of Man online. Viewed 4 Feburary 2016, $<w w w . r u p e s t r e . n e t /$ tracce/? $p=3675>$.

Collins, W.W. 1907. Free statia. Bloemfontein: The Friend Publishers.

Dobrez, L. 2011. Rock art, perception and the subject/ object binary. Rock Art Research 28(1): 71-83. 
Dowson, T.A. 1989. Dots and dashes: cracking the code in Bushman rock paintings. South African Archaeological Society Goodwin Series 6: 84-94.

Dowson, T.A. 1994. Reading art, writing history: rock art and social change in southern Africa. World Archaeology 25: 332-344.

Dowson, T.A. 2009. Re-animating hunter-gatherer rockart research. Cambridge Archaeological Journal 19(3): 378-387.

Dracopoli, J.L. 1969. Sir Andries Stockenstroom. Cape Town: Balkema.

Etherington, N. 2001. The Great Treks: the transformation of southern Africa, 1815-1854. London: Longman.

Hampson, J.G. 2011. Rock art regionalism and identity: case studies from Trans-Pecos Texas and Mpumalanga Province, South Africa. Unpublished PhD dissertation, University of Cambridge.

Hampson, J.G. 2013. The materiality of rock art and quartz: a case study from Mpumalanga Province, South Africa. Cambridge Archaeological Journal 23(3): 363-372.

Hampson, J.G. 2014. Conflict on the frontier: San rock art, spirituality, and historical narrative in the Free State Province, South Africa, in D. Gillette, M. Greer, M. Hayward and W. Murray (eds) Rock Art and Sacred Landscapes: 103-115. New York: Springer.

Hampson, J.G. 2015a. Rock art and regional identity: a comparative perspective. London: Routledge.

Hampson,J.G. 2015b. Presenting rock art and perceiving identity in South Africa and beyond. Time and Mind: the Journal of Archaeology, Consciousness, and Culture 8(4): 373-391.

Hampson, J.G. 2016. Embodiment, transformation and ideology in the rock art of Trans-Pecos Texas. Cambridge Archaeological Journal 26(2): 217-241.

Hampson, J.G., W.R. Challis, G.B. Blundell and C. de Rosner. 2002. The rock art of Bongani Mountain Lodge and its environs, Mpumalanga Province, South Africa: an introduction to problems of southern African rock-art regions. South African Archaeological Bulletin 57: 15-30.

Hollmann, J. 2002. Natural models, ethology and San rock-paintings: pilo-erection and depictions of bristles in south-eastern South Africa. South African Journal of Science 98: 563-567.

Johnson, R.T. 1979. Major rock paintings of South Africa. Amsterdam: Meulenhoff.

Jolly, P. 1996. Interaction between southeastern San and southern Nguni and Sotho communities c. 1400 to c. 1800. South African Historical Journal 35: 30-61.

Jolly, P. 1998. Modelling change in the contact art of the south-eastern San, southern Africa, in C. Chippindale and P.S.C. Taçon (eds) The archaeology of rock-art: 247-267. Cambridge: Cambridge University Press.

Katz, R. 1982. Boiling energy: community healing among the Kalahari !Kung. Cambridge, Mass.: Harvard University Press.
Kolben, P. 1731. The present state of the Cape of Good-Hope. London: Innys.

Lee, N. 1999. Domestic dogs in South African rock art. Pictogram 10(2): 1-9.

Legassick, M. 1989. The northern frontier to c. 1840: the rise and decline of the Griqua people, in R. Elphick and H. Giliomee (eds) The shaping of South African society, 1652-1820: 358-420. Cape Town: Maskew, Miller and Longman.

Lewis-Williams, J.D. 1981. Believing and seeing: symbolic meaning in southern African rock paintings. London: Academic Press.

Lewis-Williams, J.D. 1983. The rock art of southern Africa. Cambridge: Cambridge University Press.

Lewis-Williams, J.D. 1995. Modelling the production and consumption of rock art. South African Archaeological Bulletin 50: 143-154.

Lewis-Williams, J.D. 2006. The evolution of theory, method and technique in southern African rock art research. Journal of Archaeological Method and Theory 13(4): 343-377.

Lewis-Williams, J.D. and T.A. Dowson. 1989. Images of power: understanding Bushman rock art. Johannesburg: Southern Book Publishers.

Lewis-Williams, J.D. and D.G. Pearce. 2004. San spirituality: roots, expressions, and social consequences. Walnut Creek: Altamira Press.

Lightfoot, K.G. 1995. Culture contact studies: redefining the relationship between prehistoric and historical archaeology. American Antiquity 60(20): 199-217.

Lightfoot, K.G. and A. Martinez. 1995. Frontiers and boundaries in archaeological perspective. Annual Review of Anthropology 24(1): 471-492.

Loubser, J.H.N. and G. Laurens. 1994. Paintings of domestic ungulates and shields: hunter-gatherers and agro-pastoralists in the Caledon River Valley area, in T.A. Dowson and J.D.

Lewis-Williams (eds) Contested images: 83-118. Johannesburg: Witwatersrand University Press.

Mazel, A. 2009. Images in time: advances in the dating of Maloti-Drakensberg rock art since the 1970s, in P. Mitchell and B. Smith (eds) The eland's people: 81-97. Johannesburg: Wits University Press.

Mazel, A. 2013. Paint and earth: constructing huntergatherer history in uKhahlamba-Drakensberg, South Africa. Time and Mind: the Journal of Archaeology, Consciousness and Culture 6(1): 49-58.

May, S. and I. Domingo Sanz. 2010. Making sense of scenes. Rock Art Research 27(1): 35-42.

McDonald, J. 2000. Media and social context: influences on stylistic communication networks in prehistoric Sydney. Australian Archaeology 51:54-63.

McDonald, J. 2008. Dreamtime superhighway: an analysis of the Sydney Basin rock art and prehistoric information exchange. Canberra: ANU Terra Australis 27.

Midgely, J.F. 1949. The Orange River Sovereignty. Unpublished PhD thesis. Cape Town: University of Cape Town. 
Mitchell, P. 2002. The archaeology of southern Africa. Cambridge: Cambridge University Press.

Montgomery, C. 1914. Unpublished diary. Bloemfontein: Free State Archival Records.

Morales, R. 2005. Considerations on the art and aesthetics of rock art, in T. Heyd and J. Clegg (eds) Aesthetics and rock art: 61-74. Aldershot: Ashgate.

Morphy, H. 1994. Aesthetics across time and place: an anthropological perspective. Cambridge Archaeological Journal 4: 257-260.

Orpen, J. M. 1874. A glimpse into the mythology of the Maluti Bushmen. Cape Monthly Magazine (n.s.) 9: $1-13$.

Ouzman, S. 2003. Indigenous images of a colonial exotic: imaginings from Bushman southern Africa. Before Farming: the Archaeology and Anthropology of Hunter-Gatherers 2003/1: Article 6: 17-39.

Ouzman, S. 2005. The magical arts of a raider nation: central South Africa's Korana rock art. South African Archaeological Bulletin Goodwin Series 9: 101-113.

Paterson, A. 2012. Rock art as historical sources in colonial contexts, in M. Oland, S.M. Hart and L. Frink (eds) Decolonizing Indigenous histories: exploring prehistoric/colonial transitions in archaeology: 66-85. Tucson: University of Arizona Press.

Robinson, D.W. 2013. Drawing upon the past: temporal ontology and mythological ideology in southcentral Californian rock art. Cambridge Archaeological Journal 23(3): 373-394.

Sampson, C.G. 1974. Stone Age archaeology of southern Africa. London: Academic.

Skotnes, P. 1994. The visual as a site of meaning: San parietal painting and the experience of modern art, in T.A. Dowson and J.D. Lewis-Williams (eds) Contested images: diversity in southern African rock art research: 315-330. Johannesburg: Witwatersrand University Press.

Smith, B. W., K. Helskog and D. Morris (eds) 2012. Working with rock art: recording, presenting and understanding rock art using indigenous knowledge. Johannesburg: Witwatersrand University Press.
Smuts, K. 1999. Painting people: an analysis of the depiction of human figures in a sample of procession and group scenes from the rock art of the south Western Cape, South Africa. Unpublished M.A. thesis. Cape Town: University of Cape Town.

Solomon, A. 2011. Towards visual histories: style, interdisciplinarity and southern African rock art research. South African Archaeological Bulletin 66: 51-59.

Stow, G.W. 1905. The native races of South Africa. London: Swan Sonnenschein.

Stow, G.W. and D.F. Bleek 1930. Rock paintings in South Africa. London: Methuen.

Taçon, P.S.C. 1983. An analysis of Dorset art in relation to prehistoric culture stress. Inuit Studies 7: 41-65.

Taçon, P.S.C. 2008. Rainbow colour and power among the Waanyi of northwest Queensland. Cambridge Archaeological Journal 18(2): 163-176.

Tindall, H. 1856. Two lectures on Great Namaqualand and its inhabitants. Cape Town: Pike.

Thorp, C. 2000. Hunter-gatherers and farmers: an enduring frontier in the Caledon Valley, South Africa. Oxford: Archaeopress.

Van der Merwe, J. 1936. Die trek boere voor die Groot Trek. Unpublished PhD thesis. Leyden: Leyden University.

Van Hansen, E. 1859. Unpublished diary. Bloemfontein: Free State Archival Records.

Vinnicombe, P. 1976. People of the eland: rock paintings of the Drakensberg Bushmen as a reflection of their life and thought. Pietermaritzburg: Natal University Press.

Whitley, D.W. 2005. Putting the art back in rock art. In T. Heyd and J. Clegg's (rev.) (2005) 'Aesthetics and rock art'. Before Farming 2005/3: 1-12.

Whitley, D.W. and J. Clottes. 2005. In Steward's shadow: histories of research in the Far West and western Europe, in L.L. Loendorf, C. Chippindale and D.S. Whitley (eds) Discovering North American rock art: 161-180. Tucson: University of Arizona Press.

Wright, J.B.1971. Bushman raiders of the Drakensberg 18401870. Pietermaritzburg: University of Natal Press. 